J. Amer. Soc. Hort. SCI. 128(1):94-99. 2003.

\title{
Genetic Diversity of Basil (Ocimum spp.) Based on RAPD Markers
}

\author{
Roberto F. Vieira \\ Embrapa Recursos Genéticos e Biotecnologia, Caixa Postal 02372, Brasilia, DF, 70770-990, Brazil \\ Peter Goldsbrough \\ Department of Horticulture and Landscape Architecture, Purdue University, West Lafayette, \\ IN 47907-1165
}

\author{
James E. Simon ${ }^{1}$ \\ New Use and Natural Plant Products Program, Cook College, Rutgers University, 59 Dudley Road, New \\ Brunswick, NJ 08901-8520
}

AdDitional INDEX WORDs. Lamiaceae, molecular markers, intraspecific variability

\begin{abstract}
Aвstract. Molecular markers were used to assess genetic diversity in basil (Ocimum L. spp., Lamiaceae). Using randomly amplified polymorphic DNA (RAPD) analysis, 11 primers generated 98 polymorphic bands, ranging from 300 to 2,000 base pairs, that discriminated among 37 accessions across nine Ocimum spp. Means of genetic similarities within $O$ cimum spp. showed that the domesticated species, $O$. minimum $\mathrm{L}$. $(0.887), O$. basilicum $\mathrm{L} .(0.769)$, and $O$. $\times$ citriodorum Vis. $(0.711)$ had highest similarity indices within species, while the nondomesticated, $O$. americanum L. $(0.580), 0$. gratissimum $\mathrm{L}$. $(0.408)$, and $O$. kilimandscharicum Guerke (0.559) showed the lowest similarity. RAPD results indicated that $O$. minimum should not be considered a distinct species but rather a variety of $O$. basilicum. Consistent clusters among all but one of the $O$. $\times$ citriodorum spp., all containing citral as the major constituent, were identified using bootstrap analysis. RAPD analysis was useful in discriminating among Ocimum spp., although within species resolution will require a higher number of polymorphic bands.
\end{abstract}

The genus Ocimum (Lamiaceae) consists of about 30 species distributed in the tropics and subtropics of the Old and New Worlds, with some species cultivated in temperate areas (Paton, 1992). The main center of diversity of Ocimum spp. appears to be Africa (Hedge, 1992), with a secondary center in South America (Brazil) and Asia (India) (Sobti and Pushpangadan, 1982, Vieira and Simon, 2000).

Among Ocimum spp., common basil (O. basilicum) is the most important economically. The aromatic leaves of basil are used fresh and dried as flavorings or spices in a wide variety of foods. Volatile oils of basil are used to flavor foods, in dental and oral products, and in fragrances. Basil and other closely related Ocimum spp., all referred to collectively as basil, are also used in traditional ceremonial rituals and as medicines, and contain biologically active constituents that are insecticidal, nematicidal, fungistatic, or antimicrobial (Simon et al., 1990).

The genus Ocimum is divided into three sections: 1) section Ocimum, with appendiculate posterior stamens, which is subdivided, based on calix morphology, into subsection Ocimum (containing the most economically important species, such as $O$. basilicum, O. americanum, O. kilimandscharicum, O. minimum, and $O . \times$ citriodorum), and subsection gratissima (O. gratissimum); 2) section Hierocymum, with fascicles of hairs at the base of the posterior stamens (O. selloi Benth. and $O$. tenuiflorum L.), and 3 )

Received for publication 9 June 2000. Accepted for publication 22 Oct. 2002. The authors wish to thank Alan Paton, Royal Botanical Gardens, Kew, United Kingdom, Ulyssis Albuquerque, Federal University of Pernambuco, Recife, PE, Brazil and Art Tucker, Delaware State College, Dover, Del., for assistance in the taxonomy of the Ocimum collection reported in this study. We also thank Antonio Figueira, Cena, São Paulo University, São Paulo, SP, Brazil for assistance with the RAPD protocol. This project was funded in part by the Brazilian Agricultural Research Corporation (Embrapa), New Crops Center at Purdue University, and the Center for New Use and Natural Plant Products, Rutgers University.

${ }^{1}$ Corresponding author; e-mail jesimon@ aesop.rutgers.edu. section Gymnocymum, with glabrous posterior stamens $(O$. campechianum Mill.) (Paton, 1992).

Interspecific hybridization and polyploidy, common occurrences within this genus (Harley and Heywood, 1992), have created taxonomic confusion and challenges to our understanding of the genetic relationships among the multitude of basils, highlighting a need to revise the taxonomy of the genus (Tucker, 1986). Taxonomy of $O$. basilicum is also complicated by existence of numerous botanical varieties, cultivars, and chemotypes within the species that do not differ significantly in morphology (Simon et al., 1990). Morphological differences between species can be tenuous, and attempts to solve these problems with only morphology are innocuous. Taxonomic issues in this genus based on morphology and chromosome number were reviewed recently and addressed partially by Paton and Putievisky (1996).

Assays based on polymerase chain reaction (PCR), such as random amplified polymorphic DNA (RAPD) (Williams et al., 1990), provide an efficient means to produce large number of molecular markers. These can be used to estimate genetic relatedness among plants and breeding materials, to distinguish cultivars, and allow reexamination of the classification of important species delimitation (Chalmers et al., 1994, Tingey and del Tufo, 1993). A major advantage of RAPD markers over some other DNA-based markers is that they require no prior sequence information, and no prior knowledge about any particular gene in a target taxon (Palumbi, 1996). Therefore, RAPD markers can be used in the systematic study of wild plants and new crops. PCR methods require lower amounts of genomic DNA, are nonradioactive, relatively low cost, and can be developed rapidly. These characteristics facilitate screening of large populations of plants.

Several studies have highlighted the benefits of RAPD markers to assess genetic diversity in crops, including blueberry (Vaccinium L. spp.) (Levi and Rowland, 1997), Brassica L. spp. (Demeke et al., 1992; dos Santos et al., 1994), Chrysanthemum L. 
spp. (Scott et al., 1996), cranberry (Vaccinium macrocarpon (Ait.) Pursh) (Novy et al., 1994), grain amaranth (Amaranthus spp., Adams) (Transue et al., 1994), palms (Elaeis guineensis A. Cheval) (Shah et al., 1994), and white potato (Solanum tuberosum L.) (Demeke et al., 1996). RAPD markers have also been used successfully for taxonomic purposes. They have been used in discrimination of aromatic plants in Juniperus L. spp. to compare junipers (Juniperus excelsa M. Bieb.) from Saudi Arabia with J. excelsa M. Bieb. from Greece and J. procera Hochst ex Endl. from Ethiopia. Both RAPD markers and leaf terpenoids enabled identification of the Saudi Arabia junipers as J. procera (Adams et al., 1993). Most recently, RAPD markers have been used successfully in differentiating chemotypes of O.gratissimum (Vieira et al., 2001). They have also been reported useful in classification of Brassica spp. (Demeke et al., 1992) at the taxonomic level ranging from individuals, to cultivars and species; in coffee (Coffea L. spp) (Orozco-Castill et al., 1996); and cocoa (Theobroma L. spp.) (Figueira et al., 1994). When used in concert with other plant characteristics such as morphology, chromosome number, chemical constituents, and other molecular markers, RAPD markers can provide a robust classification criteria that could be useful in species separation and systematic. Therefore, the objective of this research was to characterize genetic diversity within Ocimum, comparing accessions from nine species and chemotypes within Ocimum, using RAPD markers.

\section{Materials and Methods}

Plant Material. Thirty-seven accessions in nine Ocimum spp. (Table 1) obtained from Richters Seed Co., Goodwood, Ontario, Canada (12 accessions), Companion Plants, Athens, Ohio (seven accessions), Purdue University, West Lafayette, Ind., (four accessions), Embrapa, Brasília, Brazil (five accessions), U.S. Department of Agriculture (USDA) (four accessions), Kew Garden, United Kingdom (four accessions), and Nichols Garden, Albany, Oregon (one accession), were grown in the field at the Purdue University Research Station, West Lafayette. Tissue samples of fresh young leaves of the 37 accessions were collected, and placed in Eppendorf tubes, the tubes were placed immediately in liquid

Table 1. Species key number, accession name, and origin of Ocimum spp. used in RAPD analysis.

\begin{tabular}{|c|c|c|c|}
\hline Ocimum spp. & Key no. ${ }^{\mathrm{z}}$ & Accession name & Origin \\
\hline O. americanum L. var. americanum & ot32 & Bra60 & Embrapa, Brazil \\
\hline O. americanum L. var. americanum & ot5 & Kew90157 & Kew Garden, U.K. \\
\hline O. americanum L. var. pilosum (Wild) Paton & ot 21 & PI 414204 & USDA, U.S. \\
\hline O. americanum L. var. pilosum (Wild) Paton & ot75 & PI 500953 & USDA, U.S. \\
\hline O. basilicum L. 'Dark Opal' & ot38 & 'Dark Opal' & Richters Co., Canada \\
\hline O. basilicum L. 'Purple Ruffles' & ot40 & 'Purple Ruffles' & Richters Co., Canada \\
\hline O. basilicum $\mathrm{L}$. & ot2 & Kew7711 & Kew Garden, U.K. \\
\hline O. basilicum $\mathrm{L}$. & ot43 & 'Mammoth' & Richters Co., Canada \\
\hline O. basilicum $\mathrm{L}$. & ot44 & 'Sweet Basil' & Richters Co., Canada \\
\hline O. basilicum $\mathrm{L}$. & ot49 & 'Cinnamon’ & Richters Co., Canada \\
\hline O. basilicum $\mathrm{L}$. & ot69 & 'Comoro' & Purdue Univ., U.S. \\
\hline O. basilicum $\mathrm{L}$. & ot71 & Methylcinnamate & Purdue Univ., U.S. \\
\hline O. basilicum $\mathrm{L}$. & ot72 & Linalool & Purdue Univ., U.S. \\
\hline O. basilicum L. ${ }^{\mathrm{y}}$ & ot70 & 'Sweet Dani' & Purdue Univ., U.S. \\
\hline O. basilicum L. ${ }^{\mathrm{y}}$ & ot61 & 'Lemon Mrs. Burns' & Companion Plants, U.S. \\
\hline O. basilicum L. var . difforme & ot41 & 'Green Ruffles' & Richters Co., Canada \\
\hline O. basilicum L. var. thyrsiflorum & ot56 & ‘Thai’ & Richters Co., Canada \\
\hline O. basilicum L. var. thyrsiflorum & ot57 & 'Thai Siam Queen' & Richters Co., Canada \\
\hline O. campechianum Mill. & ot30 & Lbb710 & Embrapa, Brazil \\
\hline O. gratissimum $\mathrm{L}$. & ot 26 & Bra43 & Embrapa, Brazil \\
\hline O. gratissimum $\mathrm{L}$. & ot 27 & Bra78 & Embrapa, Brazil \\
\hline O. gratissimum $\mathrm{L}$. & ot63 & ‘Tree' & Companion Plants, U.S. \\
\hline O. gratissimum $\mathrm{L}$. & ot65 & 'Green’' & Companion Plants, U.S. \\
\hline O. gratissimum $\mathrm{L}$. & ot80 & PI 500952 & USDA, U.S. \\
\hline O. gratissimum L. & ot84 & $\mathrm{Pu}$-geraniol & Purdue Univ., U.S. \\
\hline O. kilimandscharicum Guerke & ot79 & PI 500950 & USDA, U.S. \\
\hline O. kilimandscharicum Guerke & ot3 & Kew12290 & Kew Garden, U.K. \\
\hline O. kilimandscharicum Guerke & ot50 & 'African Blue' & Richters Co., Canada \\
\hline O. minimum $\mathrm{L}$ & ot34 & 'Bush' & Richters Co., Canada \\
\hline O. minimum $\mathrm{L}$. & ot35 & 'Spicy Globe' & Richters Co., Canada \\
\hline O. minimum $\mathrm{L}$. & ot60 & 'Dwarf Opal' & Companion Plants, U.S. \\
\hline O. selloi Benth. & ot73 & Lin 1 & Embrapa, Brazil \\
\hline O. tenuiflorum $\mathrm{L}$. & ot67 & 'Sacred' & Nichols Garden, U.S. \\
\hline O. $\times$ citriodorum $\mathrm{Vis}$. & ot53 & 'Lemon' & Richters Co., Canada \\
\hline O. $\times$ citriodorum Vis. & ot58 & 'Lemon' & Companion Plants, U.S. \\
\hline O. $\times$ citriodorum Vis. & ot62 & 'New Guinea' & Companion Plants, U.S. \\
\hline O. $\times$ citriodorum $\mathrm{Vis}$. & ot1 & Kew365 & Kew Garden, U.K. \\
\hline
\end{tabular}

${ }^{\mathrm{z}} \mathrm{Ot}=$ Ocimum trial. Key number used in a double blind assay.

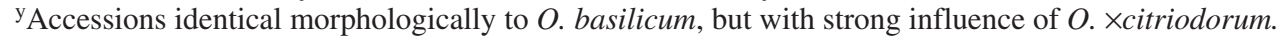


nitrogen, and maintained at $-80{ }^{\circ} \mathrm{C}$ until used. Voucher specimens of each accession included in this research were collected, dried, and deposited at the Ralph Kriebel Herbarium, Purdue Univ. Vouchers were also sent to the Royal Botanical Garden, Kew, United Kingdom, Delaware State University, Dover, Del., and Embrapa Recursos Genéticos e Biotecnologia herbaria, Brasilia, for permanent collection and repository. Taxonomic identification was conducted in collaboration with A. Paton, Royal Botanical Gardens, Kew, United Kingdom; A. Tucker, Delaware State University, and U. Albuquerque, Federal University of Pernambuco, Recife, PE, Brazil.

DNA EXTRACTION. The DNA extraction protocol used was that of Doyle and Doyle (1987). Samples were ground with liquid nitrogen, and transferred quickly to another Eppendorf tube. Hexadecyltrimethylammonium bromide (CTAB) extraction buffer (700 $\mathrm{mL}$ ) was added and the mixture was incubated for $60 \mathrm{~min}$ at $65^{\circ} \mathrm{C}$. An equal volume of 24 chloroform:1 isoamyl alcohol (v/v) was added to each sample. Samples were centrifuged for $8 \mathrm{~min}$ at 13,000 $g_{\mathrm{n}}$ and $600 \mathrm{~mL}$ of the aqueous layer supernatant was removed to a clean test tube. Cold $\left(-20^{\circ} \mathrm{C}\right)$ isopropanol $(700 \mathrm{~mL})$ was then added, and samples were placed in a freezer at $-80^{\circ} \mathrm{C}$ for $1 \mathrm{~h}$, centrifuged for $8 \mathrm{~min}$ at 13,000 $g_{\mathrm{n}}$ to collect the precipitated nucleic acids, and the supernatant discarded. The pellet was washed with $1 \mathrm{~mL}$ of $70 \%$ ethanol, centrifuged for $8 \mathrm{~min}$ at $13,000 \mathrm{~g}_{\mathrm{n}}$, and the supernatant removed carefully. Pellets were then dried, resuspended in $200 \mathrm{~mL}$ Tris-EDTA, and treated with RNAse for $30 \mathrm{~min}$. The concentration of DNA was estimated by agarose gel electrophoresis and comparison with a DNA ladder of known concentration and using spectrophotometry with absorbance at $260 \mathrm{~nm}$. Working stocks of DNA were then prepared based on both estimates.

PCR AMPLifiCATION. Nineteen arbitrary decamer oligonucleotide primers (Operon Technologies, Inc., Alameda, Calif.) were tested and 11 were selected and then used for PCR amplification following the procedures of Williams et al. (1990). Amplifications were performed in $25-\mathrm{mL}$ volumes containing 50 to $200 \mathrm{ng}$ of template DNA, PCR buffer $(50 \mathrm{~mm} \mathrm{KCl,} 10 \mathrm{~mm}$ Tris- $\mathrm{HCl} \mathrm{pH} 8.8$, $1.5 \mathrm{~mm} \mathrm{MgCl}_{2}$, and $0.1 \%$ Triton X-100), $0.1 \mathrm{~mm}$ of each dNTP, 0.2 mM primer, and 1 unit Taq DNA polymerase. All reactions were overlaid with $1 \mathrm{~mL}$ of mineral oil before amplification. Amplifications were performed in a TwinBlock thermocycler (Ericomp, San Diego) programmed for 45 cycles of denaturing for $20 \mathrm{~s}$ at $94{ }^{\circ} \mathrm{C}$; annealing for $40 \mathrm{~s}$ at $37^{\circ} \mathrm{C}$; and extension for $1 \mathrm{~min}$ at $72^{\circ} \mathrm{C}$. PCR products were electrophoresed on a $1.5 \%$ agarose gel at $100 \mathrm{~V}$ for $3 \mathrm{~h}$, stained with ethidium bromide, and visualized under ultraviolet light. A negative control lacking template DNA was included in each set of amplification reactions.

DATA ANALYSIS. The presence of a specific band of amplified DNA was scored as 1 or 0 if absent, for all prominent bands within the fingerprint. Dice's index (Hillis et al., 1996) of similarity was used, as follows: $\mathrm{d}(\mathrm{J}, \mathrm{K})=2$ $\mathrm{Nj}, \mathrm{k} / \mathrm{Nj}+\mathrm{Nk}$; where $\mathrm{J}$ and $\mathrm{K}$ are two different individuals; $\mathrm{N}_{\mathrm{j}, \mathrm{k}}$ is the number of shared fragments; and $\mathrm{N}_{\mathrm{j}}$ and $\mathrm{N}_{\mathrm{k}}$ are the total number of fragments of plants $\mathrm{J}$ and $\mathrm{K}$, respectively. A phenogram was constructed using the unweighted pair-group method with arithmetical average (UPGMA). Numerical taxonomic system (NTSYS) was used to perform the cluster analysis (Rholf, 1995). Bootstrap analysis was performed using Winboot software (Yap and Nelson, 1996).

\section{Results and Discussion}

Among 19 primers tested, 11 generated 98 polymorphic fragments ranging from 300 to 2000 base pairs (bp), in the accessions examined as follows: OPC-01 (TTCGAGCCAG) with five fragments of 500-1300 bp; OPC-06 (GAACGGACTC) with nine fragments of 300-2000 bp; OPC-08 (TGGACCGGTG) with eight fragments of 500-1300 bp; OPC-13 (AAGCCTCGTC) with six fragments of 800-2000 bp; OPG-02 (GGCACTGAGG) with 11 fragments of 300-1500 bp; OPG-04 (AGCGTGTCTG) with eight fragments of 300-1500 bp; OPG-05 (CTGAGACGGA) with seven fragments of 550-1500 bp; OPG-10(AGGGCCGTCT) with 10 fragments of 500-1600 bp; OPG-13 (CTCTCCGCCA) with 17 fragments of 350-1350 bp; OPG-14 (GGATGAGACC) with 10 fragments of 500-1400 bp; and OPG-19 (GTCAGGGCAA) with seven fragments of 500-1500 bp. Typical reaction products with primer OPG-13 are illustrated in Fig. 1.

Means of genetic similarities within Ocimum spp., as revealed by RAPD analysis indicated that $O$. minimum $(0.887), O$. basilicum (0.769), and $O$. × citriodorum $(0.711)$ have the highest within species similarity indices (Table 2 ). In contrast, $O$. americanum (0.580), O. gratissimum (0.408), and O. kilimandscharicum $(0.559)$ showed lower similarity within species (Table 2$)$. These results indicate that within the cultivated species (O. basilicum, $O$. minimum, and $O$. $\times$ citriodorum), the accessions are more homogeneous. A higher level of polymorphism is indicative of the heterogeneity in nondomesticated species, such as $O$. selloi and O. tenuiflorum.

Fig. 1. RAPD profile of Ocimum spp. generated by primer OPG-13. M = molecular weight marker in bp; lanes $1-2=0$. americanum var. americanum, lanes 3-4 = O. americanum var. pilosum, lanes 5-7 = O. kilimandscharicum, lanes $8-10=O$. minimum, lanes $11-22=$ O. basilicum, lanes $23-28=O$. $\times$ citriodorum, lane $29=$ O. campechianum, lane $30=$ O. selloi, lane $31=O$. tenuflorum, and lanes 32-37 = O. gratissimum.

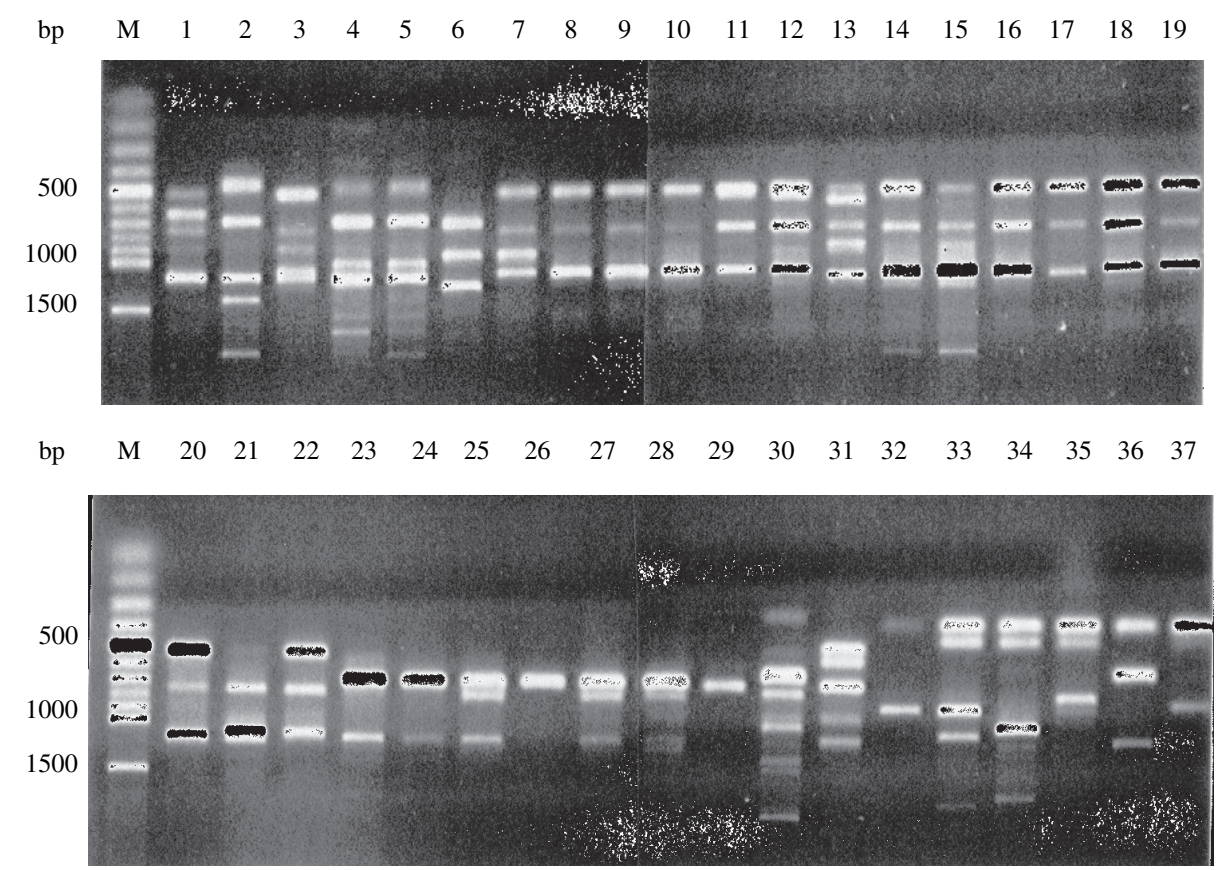


Table 2. Means of similarity values between and within Ocimum spp. based on RAPD markers.

\begin{tabular}{|c|c|c|c|c|c|c|c|c|c|c|c|}
\hline \multirow{2}{*}{$\begin{array}{l}\text { Section/subsection } \\
\text { and species }\end{array}$} & \multicolumn{10}{|c|}{ Species $^{\mathrm{z}}$} & \multirow{2}{*}{$\begin{array}{l}\text { Within } \\
\text { species }\end{array}$} \\
\hline & ame & pil & bas & $\mathrm{x}$ cit & kil & $\min$ & gra & sel & ten & cam & \\
\hline \multicolumn{12}{|l|}{$\overline{\text { Ocimum/Ocimum }}$} \\
\hline Ocimum americanum var. americanum & 1.000 & & & & & & & & & & \multirow[t]{2}{*}{$0.580^{\mathrm{y}}$} \\
\hline Ocimum americanum var. pilosum & 0.578 & 1.000 & & & & & & & & & \\
\hline Ocimum basilicum & 0.530 & 0.671 & 1.000 & & & & & & & & 0.769 \\
\hline Ocimum $\mathrm{x}$ citriodorum & 0.494 & 0.582 & 0.630 & 1.000 & & & & & & & 0.711 \\
\hline Ocimum kilimandscharicum & 0.429 & 0.485 & 0.433 & 0.438 & 1.000 & & & & & & 0.559 \\
\hline Ocimum minimum & 0.502 & 0.663 & 0.802 & 0.649 & 0.438 & 1.000 & & & & & 0.887 \\
\hline \multicolumn{12}{|l|}{ Ocimum/Gratissima } \\
\hline Ocimum gratissimum & 0.300 & 0.325 & 0.374 & 0.333 & 0.251 & 0.370 & 1.000 & & & & 0.408 \\
\hline \multicolumn{12}{|l|}{ Hierocymum/Foliosa } \\
\hline Ocimum selloi & 0.421 & 0.445 & 0.531 & 0.442 & 0.375 & 0.580 & 0.348 & 1.000 & & & $--{ }^{x}$ \\
\hline Ocimum tenuiflorum & 0.233 & 0.244 & 0.212 & 0.186 & 0.285 & 0.264 & 0.286 & 0.320 & 1.000 & & --- \\
\hline \multicolumn{12}{|l|}{ Gymnocymum } \\
\hline Ocimum campechianum & 0.311 & 0.554 & 0.356 & 0.390 & 0.258 & 0.374 & 0.243 & 0.263 & 0.178 & 1.000 & --- \\
\hline
\end{tabular}

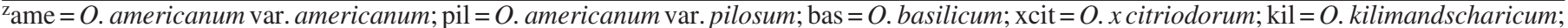
$\min =O$. minimum $;$ gra $=O$. gratisissimum $;$ sel $=O$. selloi $;$ ten $=O$. tenuiflorum $;$ and cam $=O$. campechianum .

${ }^{\mathrm{y}}$ Mean represents both varieties of $O$. americanum.

${ }^{\mathrm{x}}$ Only one accession.

The cluster of $O$. basilicum showed some specific relationships between cultivated basil varieties (Table 1 and Fig. 2). 'Purple Ruffles' (ot40), a cross between 'Dark Opal' (ot38) and 'Green Ruffles' (ot41), and 'Dark Opal' (ot38) clustered very closely (0.945). 'Purple Ruffles' showed an index of similarity of 0.815 with 'Green Ruffles', and 'Dark Opal' 0.783 . The closest genetic similarity $(0.960)$ was observed between accessions ot56 ('Thai') and ot57 ('Thai Siam Queen'), and these appeared to be morphologically and chemically similar varieties of $O$. basilicum.

'Mammoth' (ot43), 'Sweet Basil' (ot44) and 'Cinnamon' (ot49) form another cluster within O. basilicum spp. 'Mammoth' and 'Sweet Basil' are both green basil types with linalool and methylchavicol as major oil constituents, while 'Cinnamon' basil has some purple pigmentation in stem and leaf veins, and has methyl (E)-cinnamate as a major constituent. An improved line (ot71) of the aromatic phenylpropanoid methyl (E)-cinnamate that was bred by Simon and Morales (unpublished) clustered apart from the generic commercial 'Cinnamon' basil (0.732) indicating that it is genetically less similar from the other commercial source of methyl (E)-cinnamate. Methyl (E)-cinnamaterich plants have been reported for O. basilicum, O. americanum, and $O$. kilimandscharicum.

Ocimum basilicum group showed a high similarity index (Table 2) when compared to O. minimum (0.802), which some taxonomists consider a variety of $O$. basilicum (Darrah, 1980; Sobti and Pushpangadan, 1982). Paton and Putievsky (1996) considered it partially isolated reproductively from $O$. basilicum. Ocimum minimum is also relatively close to $O$. americanum var. pilosum (0.663) and $O$. ×citriodorum (0.649).

Although results obtained by cluster analysis do not show a high consensus tree for all accessions, some clusters can be discussed as they show an interesting relationship with morphological taxonomy. An arbitrary threshold of $70 \%$ similarity index places $O$. minimum inside $O$. basilicum species cluster, suggesting they are closely related. Ocimum minimum is considered by some taxonomists to be its own species, while others consider it a variety of $O$. basilicum. Our RAPD marker results strongly suggest that it should not be considered a distinct species, but rather a variety of $O$. basilicum.
Ocimum $\times$ citriodorum, considered to be a natural hybrid between $O$. basilicum and O. americanum (Paton and Putievsky, 1996) showed a high similarity index when compared to $O$. basilicum (0.630) and O. minimum (0.649). 'Comoro' basil (ot69), which was considered by Paton and Tucker (personal communication) as $O$. basilicum, showed a high similarity with the $O$. $\times$ citriodorum accessions, being very close to ot70 ('Sweet Dani') (0.889), ot58 (lemon basil from Companion Plants) (0.857), and ot61 ('Lemon Mrs. Burns') (0.808). 'Sweet Dani', a citralrich cultivar developed at Purdue University by Morales and Simon (1997) showed a very high similarity index with the $O$. $\times$ citriodorum accessions, although it was denominated by Paton as $O$. basilicum with strong morphological influence of $O$. $\times$ citriodorum. 'Sweet Dani' was developed from an O. basilicum population (Morales and Simon, 1997) originally from an accession rich in linalool and geraniol (Simon et al. 1990). The same situation was observed in 'Lemon Mrs. Burns', also considered morphologically as $O$. basilicum.

According to DeBaggio and Belsinger (1996), lemon basil was first introduced into the United States from Thailand by the USDA in 1940. The lemon basil introduced from Thailand appears to be a true $O$. × citriodorum, while 'Lemon Mrs. Burns' appears to be a segregant population from $O$. basilicum that was selected naturally for its citral aroma. 'Sweet Dani' was selected from an $O$. basilicum population originally from Yugoslavia (Morales and Simon, 1997), though results obtained with RAPD markers suggest it should be classified as $O$. × citriodorum. The morphological characters of 'Sweet Dani' (ot70) resemble those of $O$. ×citriodorum, as the cultivar produces copious amounts of citral and it clustered with $O$. $\times$ citriodorum in our analysis. These observations when grouped together provide strong evidence that its original taxonomic assignment in $O$. basilicum is questionable on genetic grounds though it was reported originally as $O$. basilicum. Both $O$. basilicum lemon cultivars ('Sweet Dani' = ot70 and 'Lemon Mrs. Burns' = ot61) appear consistently (bootstrap value $=73.3$ ) closer to each other than to the generic lemon basil (a truly natural hybrid $O$. $\times$ citriodorum).

Comparing species from section Ocimum subsection Ocimum, O. americanum var. americanum showed low similarity index 
(0.578) when compared to O. americanum var. pilosum. However, O. americanum var. pilosum appears to have higher genetic similarity to $O$. basilicum (0.671) and O. minimum (0.663). Paton (1992) considered $O$. americanum very closely related to, and difficult to distinguish morphologically from, O. basilicum. However, in this study using RAPD markers, O. basilicum was clearly distinguishable from both $O$. americanum varieties using RAPD markers (Fig. 2).

Accession ot32 (O. americanum var. americanum) is a methyl (E)-cinnamate-rich accession (Vieira and Simon, 2000), and has a low similarity index $(0.528)$ compared to the other $O$. americanum variety (ot5), an anisole-rich chemotype. Ocimum americanum is found in several different countries, and distinct chemotypes have been reported, such as a citral type in India (Sarin et al., 1992), a camphor type from Africa (Demissew, 1993), and a methyl (E)-cinnamate chemotype from Brazil (Vieira and Simon, 2000). We found ot5 to be close to ot75 (0.755), an accession of $O$. americanum var. pilosum, which is rich in 1,8-cineole and camphor (Simon et al., 1990). This large variability in chemotypes might explain the cluster separation of $O$. americanum from other species. Considering the average of similarity indices within each species of subsection Ocimum, O. kilimanscharicum was the least similar genetically (0.559) (Table 2). Ocimum kilimandscharicum is a perennial shrub, originally from Africa (Uganda, Kenya, Tanzania, and Rwanda) (Paton, 1992), growing naturally in the grassland, and disturbed ground. Ocimum kilimandscharicum contains mostly large amounts of camphor, although an African blue, a hybrid between $O$. basilicum 'Dark Opal' and $O$. kilimandscharicum have shown large amounts of linalool. The

Similarity Index

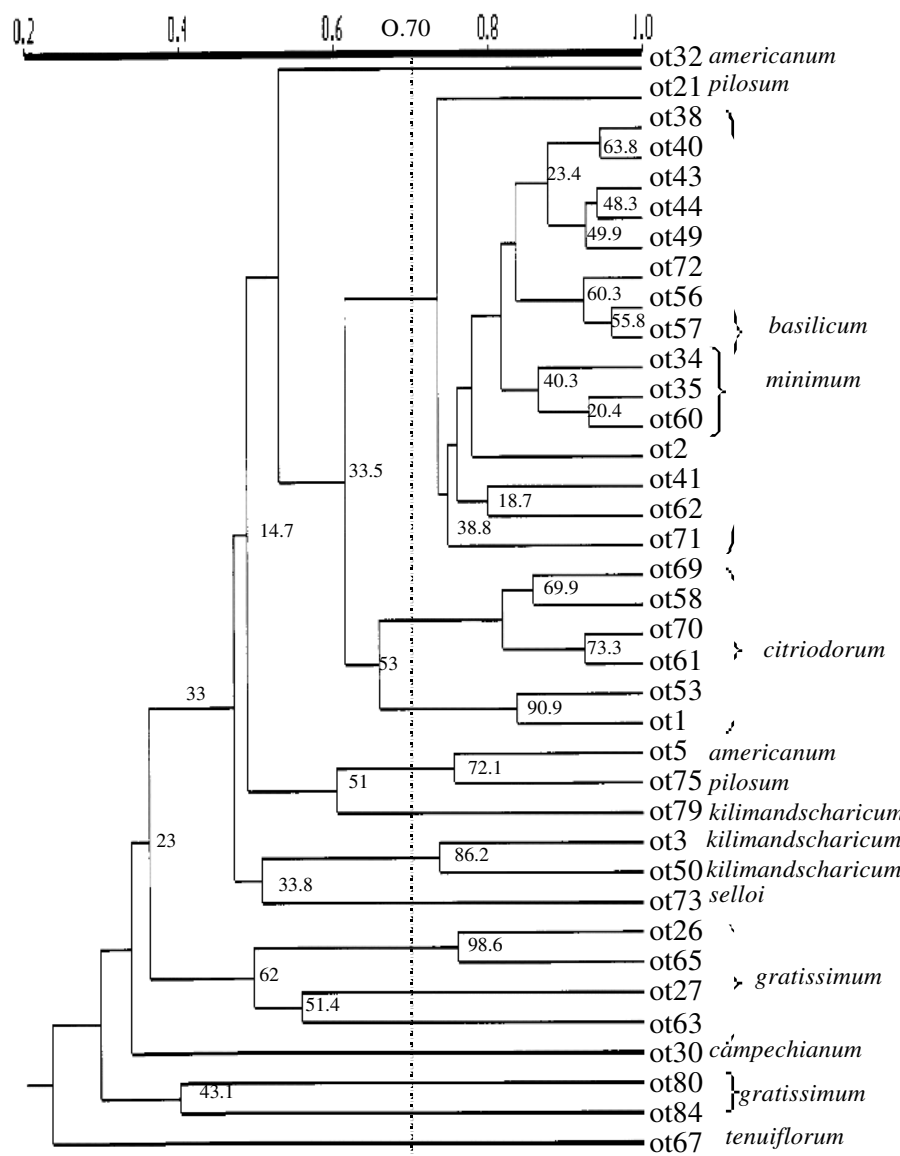

chemical and morphological heterogeneity of accessions might explain the low similarity indices presented.

In the section Ocimum subsection gratissima, O. gratissimum had the lowest similarity index (0.408) compared to all other within species indices (Table 2), clustering in a separated group, which we observed to be quite heterogeneous ( 0.408 similarity index among all $O$. gratissimum accessions). Ocimum gratissimum species were divided into two subclusters, consisting of thymol (ot27 and ot63) and eugenol (ot26 and ot65) types, in agreement with Vieira et al. (2001). The two other accessions of $O$. gratissimum, ot84 and ot80, were the most dissimilar being placed far away from the main group. The first is a geraniol type of $O$. gratissimum developed from a commercial source of tree basil (Charles and Simon, 1992), while the other (ot80) appears to be a hybrid between $O$. lamiifolium and either $O$. americanum or O. basilicum (A.O.Tucker, personal communication), although Paton classifies it as $O$. gratissimum (A. Paton, personal communication).

The species belonging to the section Hierocymum and Gymnосутит were separated and in isolation from all other species (Fig. 2), for $O$. tenuiflorum, $O$. selloi, and $O$. campechianum. Although $O$. tenuiflorum and $O$. selloi belong to the same section, they exhibited only $32 \%$ similarity. Also, $O$. selloi appears to be genetically more related to the section Ocimum than to section Hierocymum (O. tenuiflorum), though additional species from both sections would need to be analyzed before reevaluating their current systematic position.

Cluster analysis of the genetic similarity values based on RAPD generated a phenogram showing genetic relationships within and between Ocimum spp. (Fig. 2). The number at the fork shows the percentage of times the group consisting of the species that are to the right of that fork occurred. Bootstrap analysis (2000 times) showed robust clusters $(>70 \%)$ between accessions belonging to the citral group, ot69/ot58, ot70/ot61, and ot53/ot1. Accessions of $O$. americanum var. americanum (ot5) and var. pilosum (ot75) showed $72.1 \%$ consistency. The cluster between accessions ot 50 and ot 3 , the first a hybrid between $O$. basilicum and $O$. kilimandscharium, and the second, a true $O$. kilimandscharicum, showed $86.2 \%$ consensus. O. gratissimum accessions, ot65 and ot 26 , showed a consensus cluster of $98.6 \%$, both rich in eugenol.

RAPD analysis associated with volatile oils and flavonoids has been reported for $O$. gratissimum (Vieira et al., 2001), where it was shown to be an effective fingerprinting technique for that Ocimum spp. to detect intra- and interspecific variation. In this study, RAPD analysis enabled us to construct a phenogram showing the genetic similarity and cluster of a wide collection of Ocimum spp. (Table 1, Fig. 2). Analyses of the RAPD markers showed that most Ocimum spp. are distinguishable. High polymorphism was detected between species, which can be explained by the large genetic and geographic distance between each species, such as $O$. selloi and $O$. campechianum, originally from South America, and O. tenuiflorum, considered to originate in India.

The present investigation has demonstrated that RAPD markers can be applied to discriminate among Ocimum spp. The large number of polymorphic bands indicates there is large genetic

Fig. 2. Phenogram derived from 37 accessions of Ocimum and 98 RAPD bands using Dice similarity index (Hillis et al., 1996) and UPGMA. Dotted line equals arbitrary line of $70 \%$ similarity. Fork number indicates the percentage of times the cluster occurred in a bootstrap analysis. 
variation within Ocimum. This was expected given the wide morphological, chemical characteristics, and ploidy levels. However, within $O$. basilicum cultivars, the RAPD markers showed narrow genetic variation.

\section{Literature Cited}

Adams, R.P., T. Demeke, and H.A. Abulfatih. 1993. RAPD DNA fingerprinting and terpenoids: Clues to past migrations of Juniperus in Arabia and east Africa. Theor. Appl. Genet. 87:22-26.

Chalmers, K.J., A.C. Newton, R. Waugh, J. Wilson, and W. Powell. 1994. Evaluation of the extent of genetic variation in mahoganies (Meliaceae) using RAPD markers. Theor. Appl. Genet. 89:504-508.

Charles, D.J. and J.E. Simon. 1992. A new geraniol chemotype of Ocimum gratissimum L. J. Essential Oil Res. 4:231-234.

Darrah, H.H. 1980. The cultivated basils. Buckeye Printing Co., Independence, Mo.

De Baggio, T. and S. Belsinger. 1996. Basil: An herb lover's guide. Interweave Press, Loveland, Colo.

Demeke, T., R.P. Adams, and R. Chibbar. 1992. Potential taxonomic use of random amplified polymorphic DNA (RAPD): A case study in Brassica. Theor. Appl. Genet. 84:990-994.

Demeke, T., D.R. Lynch, L.M. Kawchuk, G.C. Kozub, and J.D. Armstrong. 1996. Genetic diversity of potato determined by random amplified polymorphic DNA analysis. Plant Cell Rpt. 15:662-667.

Demissew, S. 1993. A description of some essential oil bearing plants in Ethiopia and their indigenous uses. J. Essential Oil Res. 5:465-479.

dos Santos, J.B., J. Nienhuis, P. Skroch, J. Tivang, and M.K. Slocum. 1994. Comparison of RAPD and RFLP genetic markers in determining genetic similarity among Brassica oleraceae L. genotypes. Theor. Appl. Genet. 87:909-915.

Doyle, J.J. and J.I. Doyle. 1987. A rapid DNA isolation procedure for small quantities of fresh leaf tissue. Phytochem. Bul. 19:11-15.

Figueira, A., J. Janick, M. Levy, and P. Goldsbrough. 1994. Reexamining the classification of Theobroma cacao L. using molecular markers. J. Amer. Soc. Hort. Sci. 119:1073-1082.

Harley, R.M. and C.A. Heywood. 1992. Chromosome numbers in tropical American Labiatae, p. 211-246. In: R.M. Harley and T. Reynolds (eds.). Advances in Labiatae science. Royal Bot. Garden, London.

Hedge, I.C. 1992. A global survey of the biogeography of the Labiatae, p. 7-17. In: R.M. Harley and T. Reynolds (eds.). Advances in Labiatae science. Royal Bot. Garden, London.

Hillis, D.M., B.K. Mable, A. Larson, S.K. Davis, and E.A. Zimmer. 1996. Nucleic acids IV: Sequencing and cloning, p. 321-381. In: D.M. Hillis, C. Moritz, and B.K. Mable (eds.). Molecular systematics. Sinauer Assoc., Sunderland, Mass.

Levi, A. and L.J. Rowland. 1997. Identifying blueberry cultivars and evaluating their genetic relationships using randomly amplified polymorphic DNA (RAPD) and simple sequence repeat (SSR) anchored primers. J. Amer. Soc. Hort. Sci. 122:74-78.

Morales, M.R. and J.E. Simon. 1997. 'Sweet Dani': A new culinary and ornamental lemon basil. HortScience 32:148-149.

Novy, R.G., C. Kobak, J. Goffreda, and N. Vorsa. 1994. RAPDs identify varietal misclassification and regional divergence in cranberry [Vaccinium macrocarpon (Ait.) Pursh]. Theor. Appl. Genet. 88:1004 1010.

Orozco-Castillo, C., K.J.Chalmers, W. Powell, and R. Waugh. 1996. RAPD and organelle specific PCR re-affirms taxonomic relationships within the genus Coffea. Plant Cell Rpt. 15:337-341.

Palumbi, S.R. 1996. Nucleic acids II: The Polymerase chain reaction, p. 205-247. In: D.M. Hillis, C. Moritz, and B.K. Mable (eds.). Molecular systematics. Sinauer Assoc., Sunderland, Mass.

Paton, A. 1992. A synopsis of Ocimum L. (Labiatae) in Africa. Kew Bul. 47:403-435.

Paton, A. and E. Putievsky. 1996. Taxonomic problems and cytotaxonomic relationships between varieties of Ocimum basilicum and related species (Labiatae). Kew Bul. 51:1-16.

Rholf, F.J. 1995. NTSYS-PC numerical taxonomic and multivariate analysis system. Exeter Software, Setauket, N.Y.

Sarin, Y.K., S.G. Agarwal, R.K. Thappa, K. Singh, and B.K. Kapahi. 1992. A high yielding citral-rich strain of Ocimum americanum L. from India. J. Essential Oil Res. 4:515-519.

Scott, M.C., G. Caetano-Anolles, and R.N. Trigiano. 1996. DNA amplification fingerprinting identifies closely related Chrysanthemum cultivars. J. Amer. Soc. Hort. Sci. 121:1043-1048.

Shah, F.H., O. Rashid, A.J. Simons, and A. Dunsdon. 1994. The utility of RAPD markers for the determination of genetic variation in oil palm (Elaeis guineensis A. Cheval). Theor. Appl. Genet. 89:713-718.

Simon, J.E., J. Quinn, and R.G. Murray. 1990. Basil: A source of essential oils, p. 484-489. In: J. Janick and J.E. Simon (eds.). Advances in new crops research. Timber Press, Portland, Ore.

Sobti, S.N. and P. Pushpangadan. 1982. Studies in the genus Ocimum: Cytogenetics, breeding and production of new strains of economic importance, p. 457-472. In: C.K. Atal and B.M. Kapur (eds.). Cultivation and utilization of aromatic plants. Regional Lab. Council of Scientific and Industrial Res., Jammu-Tawi, India.

Tingey, S.V. and J.P. del Tufo. 1993. Genetic analysis with random amplified polymorphic DNA markers. Plant Physiol. 101:349-352.

Transue, D.K., D.J., Fairbanks, L.R. Robinson, and W.R. Andersen. 1994. Species identification by RAPD analysis of grain amaranth genetic resources. Crop Sci. 34:1385-1389.

Tucker, A.O. 1986. Botanical nomenclature of culinary herbs and potherbs, p. 33-80. In: L.E. Craker and J.E. Simon (eds.). Herbs, spices and medicinal plants. Haworth Press, Inc., Binghampton, N.Y.

Vieira, R.F., R. Grayer, A. Paton, and J.E. Simon. 2001. Genetic diversity of Ocimum gratissimum L. based on volatile oil constituents, flavonoids and RAPD markers. Biochem. Syst. Ecol. 29:287-304.

Vieira, R.F. and J.E. Simon. 2000. Chemical characterization of basil (Ocimum spp.) found in the markets and used in traditional medicine in Brazil. Econ. Bot. 54:207-216.

Williams, J.G.K., A.R. Kubelik, K.J. Livak, J.A. Rafalski, and S.V. Tingey. 1990. DNA polymorphisms amplified by arbitrary primers are useful as genetic markers. Nucleic Acids Res. 18:6531-6535.

Yap, I. and R.J. Nelson. 1996. Winboot: A program for performing bootstrap analysis of binary data to determine the confidence limits of UPGMA-based dendograms. IRRI Discussion Papers Ser. No. 4. Intl. Rice Res. Inst., Manila, Philippines. 